\title{
FIBER-OPTIC ACCELERATION SENSOR ON DUPLEX FIBER BRAGG STRUCTURES
}

\author{
A. Zh. Sakhabutdinov ${ }^{1}$, azhsakhabutdinov@kai.ru, \\ V.V. Chistyakov ${ }^{2}$, niokr.chistyakov@gmail.com, \\ O. G. Morozov ${ }^{1}$, microoil@mail.ru, \\ I. I. Nureev ${ }^{1}$, n2i2@mail.ru, \\ A. A. Kuznetsov ${ }^{1}$, AAKuznetsov@kai.ru, \\ L. M. Faskhutdinov ${ }^{1}$, lmfaskhutdinov@kai.ru, \\ M. V. Nosikov ${ }^{2}$, maximnosikov@gmail.com \\ ${ }^{1}$ Kazan National Research Technical University named after A. N. Tupolev, Kazan, \\ Russian Federation, \\ ${ }^{2}$ South Ural State University, Miass, Russian Federation
}

\begin{abstract}
We propose an assessment of the possibility to use narrow-band fiber Bragg structures as the basis of a measuring system for an acceleration sensor (accelerometer). The assessment of applicability is carried out on the basis of mathematical and computer simulation and analytical assessments of the model's working capacity. We propose to solve the problem by transferring a signal from the optical $(\mathrm{THz})$ to the radio frequency $(\mathrm{GHz})$ range of measurements due to the theory and technology of radiophoton methods. The result is a significant increase in the signal-to-noise ratio. We suggest to use the measuring system based on two narrow-band fiber Bragg gratings with the following two properties: central frequencies are in the optical range, and a difference of central frequencies is in the radio frequency range of the spectrum. The optical signal obtained in the optoelectronic circuit is fed to a photodetector. An analysis of the resulting electrical signal allows to make a conclusion on the magnitude and direction of the force acting along the axis of the sensor sensitivity. The magnitude of the effective inertia force is directly related to the acceleration acting on the measuring system. We propose an approach to determine the magnitude of the effective force. The approach does not require measurement of the intermediate radio frequency, and determines the dependence of the effective force on the magnitude of the dual-frequency beats modulation factor. We propose to implement the design of the sensor in such a way as to minimize the effect of temperature deviations on the measuring system as a whole.

Keywords: accelerometer; fiber optic acceleration sensor; dual-frequency laser radiation; fiber Bragg grating with discrete phase $\pi$-shift $(\pi-F B G)$; inclined filter; minimize the effect of temperature; deviations.
\end{abstract}

\section{Introduction}

Inertial navigation systems (INS) are the "vestibular apparatuses" for many controlled moving objects. Nowadays, INS have already gone far beyond the framework of traditional maritime, aviation, and space-rocket applications. INS can now be found in a wide variety of products and vehicles - from smartphones to unmanned aerial vehicles and cars. An accelerometer, i.e. a linear acceleration meter, is one of the main sensors in the INS. An information on the forward movement of an object is formed in the navigation system according to the signals of the accelerometer. Ideally, along with minimum weight, dimensions, and power consumption, the accelerometer should be invariant to the action 
of various kinds of disturbing and destabilizing operating factors. As a measuring device, the accelerometer should be as accurate as possible, that is, possess the necessary set of the following metrological characteristics: minimum sensitivity threshold, maximum possible dynamic measuring range, maximum possible signal-to-noise ratio in the entire measurement range, linear scale factor, and stable offset of the zero signal. Depending on the last parameter, accelerometers are divided into classes of application, see Table 1.

Table 1

Class of application and characteristic of the accelerometer

\begin{tabular}{c|l}
\hline \hline Class of application & $\begin{array}{l}\text { Characteristic of the accelerometer } \\
\text { (nonstable offset of the zero signal, } \mathbf{m g} \text { ) }\end{array}$ \\
\hline \hline Consumer, Automotive & $>50$ \\
\hline Industrial/ low-end tactical, AHRS & $1-3$ \\
\hline Tactical & $\sim 1$ \\
\hline Navigation & $25 \cdot 10^{-3}$ \\
\hline Strategic & $1 \cdot 10^{-3}$ \\
\hline
\end{tabular}

Consider the use of an accelerometer as a part of INS on a responsible object with high dynamics of movement (a cruise missile, a maneuvering combat unit of a ballistic missile, etc.). Nowadays, available sensors satisfy the entire set of requirements with difficulty, despite the fact that the sensors are based on a variety of physical principles.

If a measurement range is $\pm 100 \mathrm{~g}$, then the following conditions should be hold [1]:

1. Deviation of the real value of the output characteristic steepness from the certified value is no more than $0.03 \%$.

2. Zero signal (constant component) is no more than $\pm 20 \cdot 10^{-3} \mathrm{~g}$.

3 . Deviation of the real value of the zero signal from the certified value is no more than $\pm 3 \cdot 10^{-5} \mathrm{~g}$.

4. Threshold of sensitivity is not less than $1 \cdot 10^{-6} \mathrm{~g}$.

5. Nonlinearity is no more than $0.1 \%$.

6. Frequency response is such that the passband at the level minus $3 \mathrm{~dB}$ is not less than $0 \ldots 50 \mathrm{~Hz}$.

There is a main feature that combines all types of accelerometers. Namely, each accelerometer has a sensitive inertial mass. However, there are many ways to register the inertial displacement of the mass under the influence of acceleration. In this part, the use of fiber-optic Bragg structures can be a very promising tool for obtaining an accelerometer, which is highly sensitive and low-noise, has a high dynamic range, and is not sensitive to external electromagnetic radiation [2].

\section{Problem Statement}

The aim of the paper is a preliminary study of an applicability of radiophotonic sensor systems for the construction of an acceleration sensor (accelerometer) having sensitive element, which is insensitive to external magnetic or electric fields, including directional radio frequency radiation $[2,3]$. 


\section{Sensitive Element}

A drawing of the principal design of the acceleration sensor is shown in Fig. 1. Acceleration is measured along the axis OX, under the assumption that there is a projection of the effective force (the combination of inertia force, gravitational force, and centrifugal force) onto OX. Fig. 1 shows that an inert mass (4) is placed between two lateral sides of the "channel" (1), which is the rigid basis of the measuring structure.

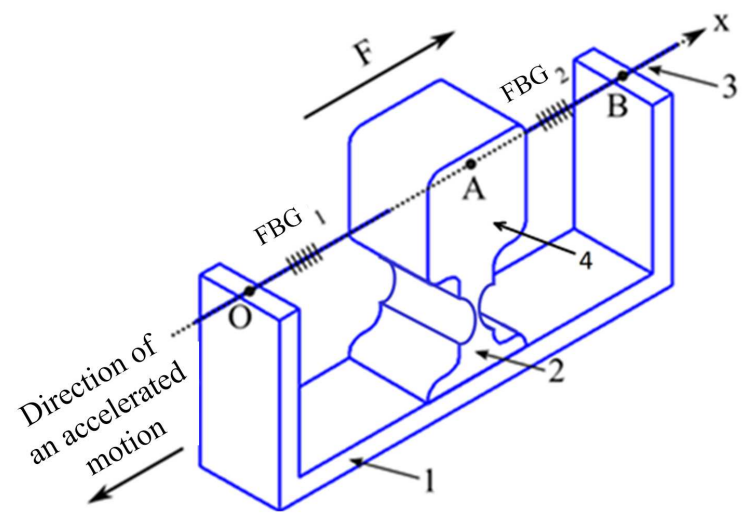

Fig. 1. The design of the sensitive element of the acceleration sensor: 1 - basis made in the form of a segment of the channel; 2 - anisotropic-elastic suspension; 3 - optical fibers; 4 - inert mass.

The design of suspension (2) of the inert mass (4) is implemented so as to eliminate or minimize any relative lateral displacement of the suspension (2) from the measuring axis OX. A through hole is made in an inert (seismic) mass (4). The optical fiber (3) is passed through the hole. Two periodic Bragg structures are formed on the optical fiber (3): fiber Bragg grating $\mathrm{FBG}_{1}$ on the first fiber section, and $\mathrm{FBG}_{2}$ on another fiber section. Working sections of the optical fiber with preliminary tension are rigidly fixed on the sides of the channel and to the inertial mass at points O, A and B (see Fig. 1), so as to ensure equality of the lengths of sections $\mathrm{AO}$ and $\mathrm{AB}$ and the same tension of the fiber sections $\mathrm{FBG}_{1}$ and $\mathrm{FBG}_{2}$. If there is a projection of the resulting acceleration along the axis $\mathrm{OX}$, then the force $\mathbf{F}$ acts on the inert mass (4) in the direction of the axis OX. The force $\mathbf{F}$ is proportional to the value of the inert mass (4) and the elastic properties of suspension (2) of the inert mass (4). Under the action of acceleration, the inert mass deviates from the equilibrium position. The deviation involves stretching of the fiber section $\mathrm{FBG}_{1}$, and simultaneously reducing the preliminary tension of the fiber section $\mathrm{FBG}_{2}$. At the same time, the Bragg frequency of $\mathrm{FBG}_{1}$ decreases, and the Bragg frequency of $\mathrm{FBG}_{2}$ increases by the same amount.

The design of the acceleration sensor involves a thermostated body, which provides a uniform temperature field inside the sensor body. Any temperature effect leads to simultaneous and uniform stretching or compression of fiber sections $\mathrm{FBG}_{1}$ and $\mathrm{FBG}_{2}$, if the distances $\mathrm{OA}$ and $\mathrm{AB}$ are equal (see Fig. 1) and there is the same preliminary tension of fiber sections $\mathrm{FBG}_{1}$ and $\mathrm{FBG}_{2}$. The difference frequency $\left(\omega_{1}-\omega_{2}\right)$ remains unchanged during a synchronous offset of the Bragg frequencies of $\mathrm{FBG}_{1}$ and $\mathrm{FBG}_{2}$ provided by a temperature effect, if there is and there is no projection of the external force $\mathrm{F}$. As will be shown later, an analysis of the resulting signal is carried out at the difference frequency between $\mathrm{FBG}_{1}$ and $\mathrm{FBG}_{2}$. Also, the synchronicity of the difference frequency 
offset provided by temperature effect on $\mathrm{FBG}_{1}$ and $\mathrm{FBG}_{2}$ allows to assign to the further research stage an assessment of the contribution of the residual effect of temperature fluctuations to the refined model of sensor errors.

\section{Measuring System}

Let us formulate the main points in the construction of the measuring system.

1. Bragg frequencies of $\mathrm{FBG}_{1}$ and $\mathrm{FBG}_{2}$ are close, but do not coincide with each other. The Bragg frequencies $\omega_{1}$ and $\omega_{2}$ are in the optical part of the spectrum (THz), and their difference frequency $\left(\omega_{1}-\omega_{2}\right)$ is in the radio frequency part of the electromagnetic spectrum $(\mathrm{GHz})[4,5]$.

2. Lines of the Bragg frequencies of $\mathrm{FBG}_{1}$ and $\mathrm{FBG}_{2}$ have small spectral width. Therefore, for any mutual arrangement of the lines in the measurement range, disjointness of the $\mathrm{FBG}_{1}$ and $\mathrm{FBG}_{2}$ spectra is provided.

3. Mechanical design of the suspension (2) of the inert mass (4) eliminates any displacement of the inert mass (4) perpendicular to the axis of sensitivity OX, see Fig. 1.

4. Entire sensor is located in a thermostatted body that provides the same (but not necessarily constant in time) temperature of both optical fiber sections $\mathrm{FBG}_{1}$ and $\mathrm{FBG}_{2}$, as well as the fact that the distances $\mathrm{OA}$ and $\mathrm{AB}$ are equal.

5. Direction of accelerated motion has a projection on the axis Ox, see Fig. 1. If the motion direction does not coincide with the axis $\mathrm{Ox}$ of the acceleration sensor, then the analysis of the acceleration magnitude is carried out in the direction of the sensor axis itself.

6. Reflection coefficients for $\mathrm{FBG}_{1}$ and $\mathrm{FBG}_{2}$ are the same. Therefore, the amplitudes of their frequency response at Bragg frequencies are equal $[2,6,7]$.

7. Frequency of change in the effect of an external force is much less than the difference frequency $\left(\omega_{1}-\omega_{2}\right)$ between the Bragg frequencies of $\mathrm{FBG}_{1}$ and $\mathrm{FBG}_{2}$.

All deviations from the given idealized features of the measuring system construction provides the appearance of the corresponding components in the general mathematical model of the sensor errors $[7,8]$.

Fig. 2 schematically shows the amplitude-frequency characteristic of the spectral response of two fiber Bragg gratings in the unperturbed state (a continuous line) and under impact of an external force projected on the axis OX (a dashed line).

Consider the moment of an external force impact. As to $\mathrm{FBG}_{1}$, there is a deformation of tension, and the Bragg frequency reduces. At the same time, as to $\mathrm{FBG}_{2}$, there are a deformation of compression of preliminary tension and an increase in the Bragg frequency. Suppose that there is no projection of the force vector on the axis of sensitivity. In this case, by virtue of a constructive implementation, if there is a shift of the central frequencies, then the shift is synchronously and by the same amount.

Note that ultra-narrow (i.e., at half height the full width of the spectrum is about $5 \mathrm{pm}$ ) fiber Bragg gratings with a high reflection coefficient (about 99\%) are extremely difficult to make. Most manufacturers, both foreign and domestic, offer fiber Bragg gratings such that at half height a full width of the spectrum is $100 \mathrm{pm}$ and more. An ultra-narrow fiber Bragg grating such that at half height a full width of the spectrum is $5 \mathrm{pm}$, a reflection coefficient is $0.99 \%$ and a wavelength is $1550 \mathrm{~nm}$ can be obtained only if a grating length is $21 \mathrm{~cm}$, and a depth of induced refractive index modulation is $0.6 \cdot 10^{5}$. 


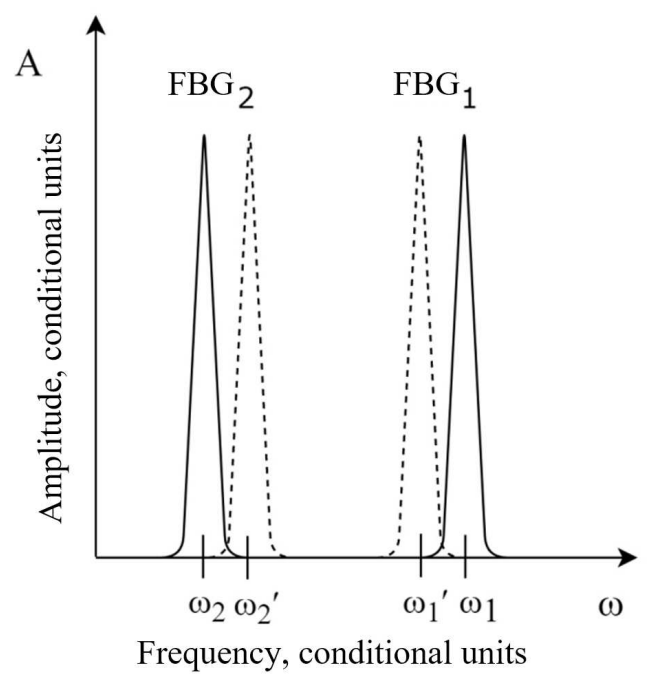

Fig. 2. The amplitude-frequency characteristic of the spectral response of two fiber Bragg gratings in the unperturbed state (a continuous line) and under impact of an external force projected on the axis OX (a dashed line).

In order to provide a practical implementation of the measuring system, we use a fiber Bragg grating with discrete phase $\pi$-shift $(\pi$-FBG).

By computer simulation in the software package OptiGrating 4.2 , we obtain $\pi$-FBG with spectral characteristic that satisfies the requirements of the measuring system. Fig. 3 shows $\pi$-FBG, consisting of two homogeneous fiber Bragg gratings, which are written one after the other with a phase shift between them. The length of homogeneous sections is $2.5 \mathrm{~mm}$, and the number of strokes is 100 . There is an apodization of the homogeneous sections by the Gauss curve with a parameter 0.5, the magnitude of the induced refraction index is $9 \cdot 10^{4}$, and the phase shift is $\frac{\pi}{2}$.

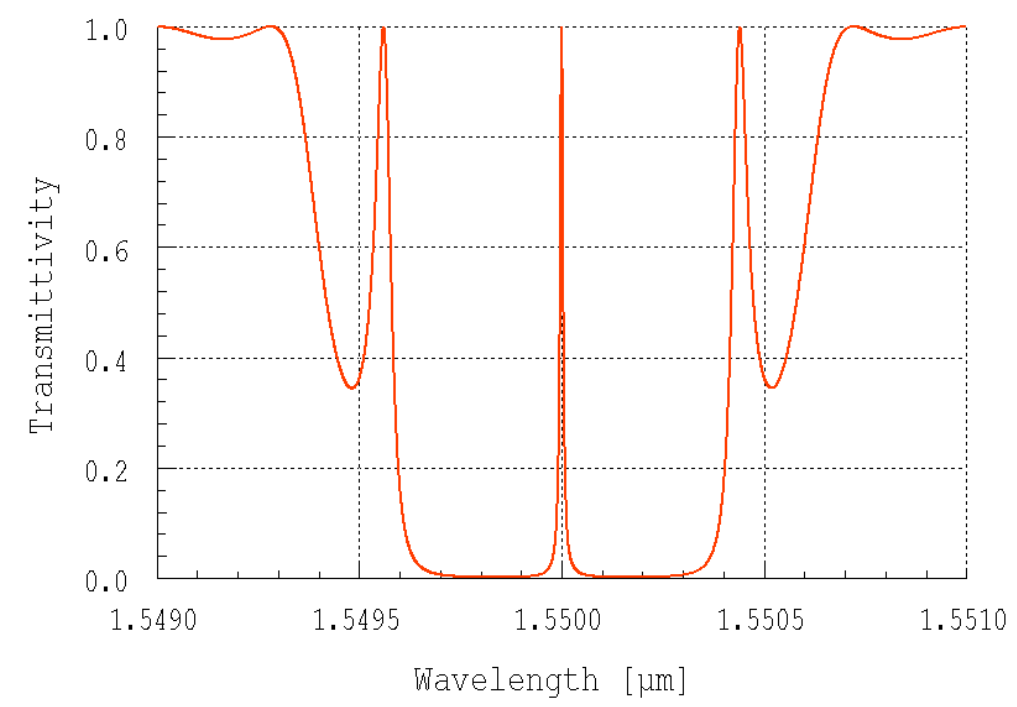

Fig. 3. Spectral characteristic of a fiber Bragg grating with discrete phase $\pi$-shift. 
The spectral characteristic of $\pi$-FBG allows to obtain single-frequency ultra-narrow radiation, if to use the light response only from central part of the spectrum, i.e., from the part, which corresponds to the position of the phase shift. To this end, we propose to use a laser source with a transmission width less than half the full width of the spectrum at half the height of $\pi$-FBG. Therefore, in fact, only the frequency range of the phase shift in its central part is highlighted. In this case, the fiber Bragg grating can be used as a resulting source of an extra narrowband signal, which is already convenient for its further processing. The full width at half the height of the spectral response from the frequency component of the phase shift is peak meters.

\section{Mathematical Model}

Fig. 4 shows the functional optoelectronic circuit of a fiber optic acceleration sensor. The wideband laser source (1) generates a continuous laser radiation, which enters two fiber sections through an optical splitter (2). Each of two fiber sections contains fiber Bragg structures $\mathrm{FBG}_{1}$ and $\mathrm{FBG}_{2}$. An external force $\mathbf{F}$ impacts in the direction of the optical fiber. Under the action of a projection of $\mathbf{F}$, an inert mass (3) moves and impacts on the optical fiber such that $\mathrm{FBG}_{1}$ is stretched (compressed) and $\mathrm{FBG}_{2}$ is simultaneously compressed (stretched). The optical signals transmitted through $\mathrm{FBG}_{1}$ and $\mathrm{FBG}_{2}$ are combined by a fiber optic power combiner (4). The resulting optical signal transmitted through $\mathrm{FBG}_{1}$ and $\mathrm{FBG}_{2}$ enters a linear filter (5) with an inclined amplitude-frequency characteristic, passes through the filter, and is fed to a photo-receiver (6). Therefore, the photo-receiver takes two-frequency laser radiation generated by the frequency responses of the fiber Bragg structures $\mathrm{FBG}_{1}$ and $\mathrm{FBG}_{2}$ with frequencies $\omega_{1}$ and $\omega_{2}$ and asymmetric amplitudes. Data from the photo-receiver is fed to a digital signal processing device, where the received data is analyzed and deciphered in real time.

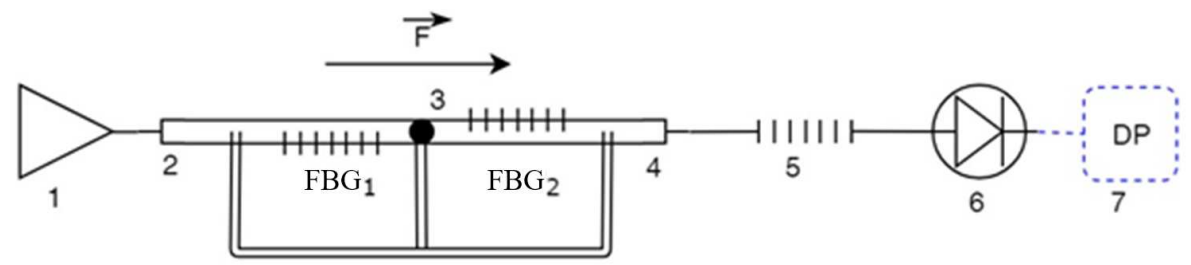

Fig. 4. Functional opto-electronic acceleration sensor circuit: 1 - wideband laser source; 2 optical splitter; $\mathrm{FBG}_{1}$ and $\mathrm{FBG}_{2}$ - fiber Bragg gratings; 3 - inert mass; 4 - fiber optic power combiner; 5 - linear filter with an inclined amplitude-frequency characteristic, 6 - photo-receiver; DP - digital processor.

Note that shift of the Bragg frequencies of $\mathrm{FBG}_{1}$ and $\mathrm{FBG}_{2}$ depends on the effective force $\mathbf{F}$ and, in the general case, the temperature $\mathrm{T}$. Therefore, there is the following functional dependence:

$$
\omega_{1}=\omega_{1}(\mathbf{F}(t), T), \quad \omega_{2}=\omega_{2}(\mathbf{F}(t), T) .
$$

According to the mentioned above features of the measuring system construction, the differential scheme of the acceleration sensor implementation allows to minimize the effect of temperature drift on the Bragg frequency difference. Therefore, for the Bragg frequency 
difference, the following equality is true in the first approximation:

$$
\omega_{1}-\omega_{2}=\Phi\left(\mathbf{F}_{x}(t)\right)=\Phi(F(t))
$$

where $\Phi\left(\mathbf{F}_{x}(t)\right)$ is the functional dependence of the difference frequency $\left(\omega_{1}-\omega_{2}\right)$ on the projection $\mathbf{F}_{x}(t)$ of the effective force $\mathbf{F}(t)$ on the direction of the sensitivity axis OX. For shortness, we denote $\mathbf{F}_{x}(t)$ by $F(t)$. Hereinafter, we use the implicit notation of Bragg frequencies in the form $\omega_{1}$ and $\omega_{2}$ as functions depending on $F(t)$.

Mathematically, the light flux in front of the photo-receiver is the sum of oscillations at frequencies $\omega_{1}$ and $\omega_{2}$ :

$$
S(t)=A_{1} \sin \left(\omega_{1} \cdot t+\varphi_{1}\right)+A_{2} \sin \left(\omega_{2} \cdot t+\varphi_{2}\right),
$$

where $A_{1}$ and $A_{2}$ are the amplitudes of the light response at Bragg frequencies, $\omega_{1}$ and $\omega_{2}$ are Bragg frequencies, $\varphi_{1}$ and $\varphi_{2}$ are phase delays. Note that the optical frequencies $\omega_{1}$ and $\omega_{2}$ are large $(\mathrm{THz})$, and the difference of optical frequencies $\left(\omega_{1}-\omega_{2}\right)$ is small $(\mathrm{MHz}-\mathrm{GHz})$ with respect to the magnitude of the frequencies themselves. Therefore, there are oscillations of beating with a difference frequency on the photo-receiver as on a quadratic low-frequency element. Consequently, the power of the electrical signal after the photo-receiver is proportional to the doubled square of the light flux (3):

$$
P(t)=2\left(A_{1} \sin \left(\omega_{1} \cdot t+\varphi_{1}\right)+A_{2} \sin \left(\omega_{2} \cdot t+\varphi_{2}\right)\right)^{2} .
$$

Note that the photo-receiver is a low-frequency optical element. Therefore, the photoreceiver is not sensitive to oscillations in the power of the light flux in the optical range. Consequently, we can exclude all terms with frequencies that exceed the sensitivity threshold of the photo-receiver from (4). In our case, such terms correspond to oscillations with frequencies higher than the modulus of the difference frequency $\left|\omega_{1}-\omega_{2}\right|$. In order to transform (4), use the following notations:

$$
\omega=\frac{\omega_{1}+\omega_{2}}{2}, \quad \Omega=\frac{\omega_{1}-\omega_{2}}{2} .
$$

Note that the following condition is identically fulfilled for the measuring system construction proposed above:

$$
\omega=\frac{\omega_{1}+\omega_{2}}{2}=\text { const. }
$$

In terms of our notation, the frequencies $\omega_{1}$ and $\omega_{2}$ can be expressed as follows:

$$
\omega_{1}=\omega+\Omega, \quad \omega_{2}=\omega-\Omega .
$$

Rewrite (4) in the new notations:

$$
P(t)=2\left[A_{1} \sin \left((\omega+\Omega) \cdot t+\varphi_{1}\right)+A_{2} \sin \left((\omega-\Omega) \cdot t+\varphi_{2}\right)\right]^{2} .
$$

Open the sum of sines in (8) and give similar terms:

$$
P(t)=2\left[\begin{array}{c}
\sin (\omega t)\left(A_{1} \cos \left(\Omega t+\varphi_{1}\right)+A_{2} \cos \left(-\Omega t+\varphi_{2}\right)\right)+ \\
+\cos (\omega t)\left(A_{1} \sin \left(\Omega t+\varphi_{1}\right)+A_{2} \sin \left(-\Omega t+\varphi_{2}\right)\right)
\end{array}\right]^{2}
$$


Let us use the following intermediate notations:

$$
\begin{aligned}
& a=A_{1} \cos \left(\Omega t+\varphi_{1}\right)+A_{2} \cos \left(-\Omega t+\varphi_{2}\right), \\
& b=A_{1} \sin \left(\Omega t+\varphi_{1}\right)+A_{2} \sin \left(-\Omega t+\varphi_{2}\right) .
\end{aligned}
$$

Consequently,

$$
P(t)=2\left(a^{2} \sin ^{2}(\omega t)+2 a b \sin (\omega t) \cos (\omega t)+b^{2} \cos ^{2}(\omega t)\right),
$$

or

$$
P(t)=2\left(a^{2} \frac{1-\sin (2 \omega t)}{2}+a b \sin (2 \omega t)+b^{2} \frac{1+\cos (2 \omega t)}{2}\right) .
$$

As a low-frequency quadratic element, the photo-receiver is not sensitive to oscillations at optical frequencies. All terms corresponded to the high-frequency oscillations on the photo-receiver are tend to zero. Therefore,

$$
P(t)=a^{2}+b^{2}
$$

Perform the reverse substitution of $a$ and $b$ in (13):

$$
\begin{aligned}
P(t)= & \left(A_{1} \cos \left(\Omega t+\varphi_{1}\right)+A_{2} \cos \left(-\Omega t+\varphi_{2}\right)\right)^{2}+ \\
& +\left(A_{1} \sin \left(\Omega t+\varphi_{1}\right)+A_{2} \sin \left(-\Omega t+\varphi_{2}\right)\right)^{2} .
\end{aligned}
$$

Simplify the expression:

$$
\begin{aligned}
P(t)= & A_{1}^{2} \cos ^{2}\left(\Omega t+\varphi_{1}\right)+A_{2}^{2} \cos ^{2}\left(-\Omega t+\varphi_{2}\right)+2 A_{1} A_{2} \cos \left(\Omega t+\varphi_{1}\right) \cos \left(-\Omega t+\varphi_{2}\right)+ \\
& +A_{1}^{2} \sin ^{2}\left(\Omega t+\varphi_{1}\right)+A_{2}^{2} \sin ^{2}\left(-\Omega t+\varphi_{2}\right)+2 A_{1} A_{2} \sin \left(\Omega t+\varphi_{1}\right) \sin \left(-\Omega t+\varphi_{2}\right),
\end{aligned}
$$

or

$$
P(t)=A_{1}^{2}+A_{2}^{2}+2 A_{1} A_{2}\left(\cos \left(\Omega t+\varphi_{1}\right) \cos \left(-\Omega t+\varphi_{2}\right)+\sin \left(\Omega t+\varphi_{1}\right) \sin \left(-\Omega t+\varphi_{2}\right)\right) .
$$

There is the difference of cosines in brackets of (16). The final expression connects the power of the electrical signal after the photo-receiver and the optical radiation falling on the photo-receiver. If we return to the original variables, then the final expression takes the form:

$$
P(t)=A_{1}^{2}+A_{2}^{2}+2 A_{1} A_{2} \cos \left(2 \Omega t+\varphi_{1}-\varphi_{2}\right)
$$

where $\left(\varphi_{2}-\varphi_{1}\right)$ is the resulting phase delay of the electrical signal.

The main problem is to determine the instantaneous difference frequency $\left(\omega_{1}-\omega_{2}\right)$ for the known value of the instantaneous power of the light flux $P(t)$. There are two ways to solve the problem. The first way (see [5]) proposes to install an instantaneous frequency meter and associate readings of the meter with the magnitude of the effective force. The measurement of the instantaneous frequency is not very difficult. At the same time, this measurement requires additional measurements, which can introduce errors into the measuring system. The second way (see [4, 5]) proposes to install a frequency filter with a linear amplitude-frequency characteristic in front of the photodetector. The filter asymmetrically changes the amplitudes of the frequency responses from $\mathrm{FBG}_{1}$ and $\mathrm{FBG}_{2}$. The parameters of the angle of inclination and displacement of a linear inclined filter are considered known and based on the parameters of the measuring system. 
There are oscillates of beats of the frequency components from $\mathrm{FBG}_{1}$ and $\mathrm{FBG}_{2}$ on the photodetector. The shape and characteristics of the parameters of the envelope curve of these beats are analyzed in order to determine the dependence of the difference frequency $\Omega$ on the modulation coefficient of the resulting oscillations. A diagram shown in Fig. 5 explains the change in the amplitude-frequency characteristic of the response of two fiber Bragg gratings that have passed through an inclined filter with a linear amplitudefrequency characteristic.

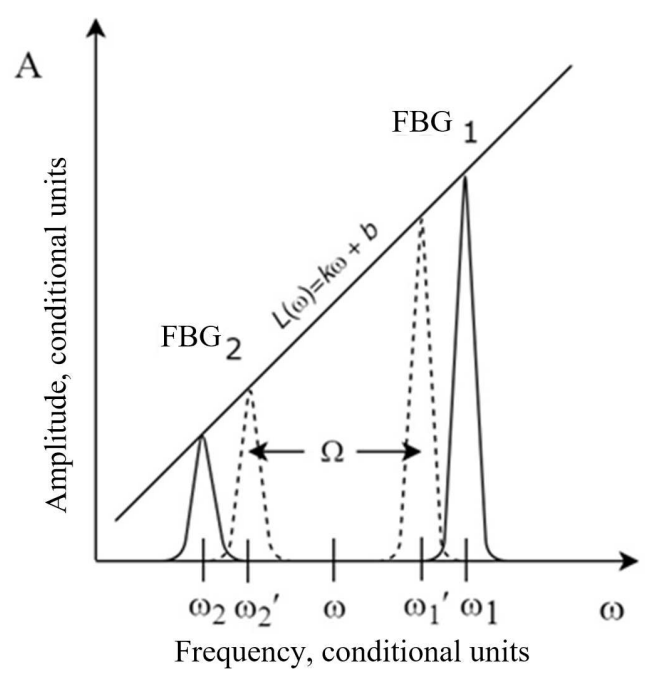

Fig. 5. Amplitude-frequency characteristic of response of two fiber Bragg gratings that have passed through an inclined filter with linear amplitude-frequency characteristic: in the unperturbed state (a continuous line) and at the time of an external force impact (a dashed line).

Define the modulation coefficient for (17) in the following form [4]:

$$
M=\frac{2 \cdot A_{1} \cdot A_{2}}{A_{1}^{2}+A_{2}^{2}} .
$$

The spectral characteristic of the linear inclined filter is given in the form of a linear relationship [5]

$$
L(\omega)=k \cdot \omega+b,
$$

where $k$ and $b$ are parameters of the straight line describing the amplitude- frequency characteristic of the linear inclined filter.

The amplitudes $A_{1}$ and $A_{2}$ of the spectral responses of $\mathrm{FBG}_{1}$ and $\mathrm{FBG}_{2}$ are changed by a linear inclined filter as follows:

$$
\begin{aligned}
& A_{1}=A_{1}\left(\omega_{1}\right)=L\left(\omega_{1}\right)=k \cdot \omega_{1}+b=k \cdot(\omega+\Omega)+b, \\
& A_{2}=A_{2}\left(\omega_{2}\right)=L\left(\omega_{2}\right)=k \cdot \omega_{2}+b=k \cdot(\omega-\Omega)+b,
\end{aligned}
$$

where the variables $\omega$ and $\Omega$ are defined by (5). Substitute (20) into (18) and obtain an expression for the modulation coefficient, which relates the average frequency of $\mathrm{FBG}_{1}$ and $\mathrm{FBG}_{2}$, i.e. $\omega=\frac{\omega_{1}+\omega_{2}}{2}$, the parameters $k$ and $b$ of the linear inclined filter, and the difference frequency $\Omega=\frac{\omega_{1}-\omega_{2}}{2}$ :

$$
M(\Omega)=\frac{(k \cdot \omega+b)^{2}-k^{2} \cdot \Omega^{2}}{(k \cdot \omega+b)^{2}+k^{2} \cdot \Omega^{2}} .
$$


The value of the difference frequency $\Omega$ varies in the range $\left(0, \Omega_{\text {Max }}\right)$, where $\Omega_{\text {Max }}=\max \left(\omega_{1}-\omega_{2}\right) \forall \omega_{1}, \omega_{2}$. Note that $\Omega_{\text {Max }}$ is determined by the parameters of the system. At the same time, $\Omega_{\text {Max }}<<\omega$, i.e. the numerator of expression (21) is always positive. Therefore, the values of the function $\mathrm{M}(\Omega)$ are in the interval $(0 ; 1)$, and the function $\mathrm{M}(\Omega)$ itself is monotonically decreasing $\left(M^{\prime}(\Omega)<0 \forall \Omega>0\right)$ for $\Omega \in\left(0, \Omega_{\text {Max }}\right)$. The monotonicity of the modulation coefficient $\mathrm{M}(\Omega)$ for $\Omega \in\left(0, \Omega_{\text {Max }}\right)$ allows to associate the difference frequency $\Omega$ with the value of the modulation coefficient uniquely.

Note that, in the general case, the problem to determine the modulation coefficient does not require determining the difference frequency $\Omega$, and the value of the modulation coefficient itself contains all the information necessary to determine the difference frequency $\Omega$.

\section{Sensor Calibration}

Since the modulation coefficient $\mathrm{M}(\Omega)$ of the resulting oscillation is determined, we can solve the problem on determination of the difference frequency $\Omega$. At the same time, taking into account the monotonous dependence of the modulation coefficient $\mathrm{M}(\Omega)$ on the difference frequency $\Omega$, we can omit the intermediate calculations, and construct a functional dependence of the force $F$ acting in the direction of the axis OX on the modulation coefficient $\mathrm{M}(\Omega)$ :

$$
F(M(\Omega))=\sum_{k=0}^{K} c_{n} M^{k}(\Omega),
$$

where $c_{k}$ are the coefficients of the approximating polynomial, and $K$ is the degree of the approximating polynomial.

In order to determine the dependence coefficients (22), we use the least squares method. To this end, first of all, a series of $N$ measurements is carried out on a test bench. Second, we form a set of magnitudes of the given external force $F_{i}$ and measured values of the modulation coefficient $M_{i}(\Omega), i=1,2, \ldots, N$. Then, we find the minimum of the functional

$$
\Psi\left(c_{0}, c_{1}, \ldots, c_{n}\right)=\sum_{i=1}^{N}\left(F_{i}-\sum_{k=0}^{K} c_{k} M_{i}^{k}(\Omega)\right)^{2} \rightarrow \min ,
$$

where $N$ is the number of control measurements, $F_{i}$ is the magnitude of the effective force on each dimension, $M_{i}(\Omega), i=1,2, \ldots, N$ is the magnitude of the modulation factor for each dimension. The result is the desired expression for the dependence of the effective force on $\mathrm{M}(\Omega)$. In order to ensure maximum accuracy of the approximation, measurements are taken for the entire range of changes in the external force. The search for the degree $K$ of dependence (22) is carried out by gradually increasing the value of $K$ until the coefficient $c_{K}$ at the highest degree becomes close to zero (obviously less than the predetermined value $\varepsilon$ ).

\section{Computer Model}

Computer simulation was carried out in the OptiSystem 7.0 software package. We simulated the signal processing circuit, which is equivalent to a functional optoelectronic 
circuit. To this end, $\mathrm{FBG}_{1}$ and $\mathrm{FBG}_{2}$ were preliminary simulated in the OptiGrating 4.2 software package: the central wavelength is $1550 \mathrm{~nm}$, and the simulation parameters are the same as given above for Fig. $3 . \mathrm{FBG}_{1}$ and $\mathrm{FBG}_{2}$ are identical in reflection coefficient (0.99) and contour quality factor (full width of the spectral response formed by the phase $\pi$-shift at half height is $88.3 \mathrm{MHz}(\approx 7.3 \mathrm{pm}))$. $\mathrm{FBG}_{1}$ and $\mathrm{FBG}_{2}$ are different only in the central wavelength. An equivalent computer optoelectronic circuit for interrogating the acceleration sensor is shown in Fig. 6.

Laser source (1), i.e. the laser, generates continuous laser radiation, which is directed through an optical splitter (2) Power Splitter to a pair $\mathrm{FBG}_{1}$ (3.1) and $\mathrm{FBG}_{2}$ (3.2). The optical response from the fiber Bragg gratings generates dual-frequency laser radiation, which is combined on an optical power combiner (4) Power Combiner and fed to a linear inclined filter (5) FBG Mirror. The filter is also used as a tool that cuts off the side frequency components that are not involved in the analysis. The situational spectral response from $\mathrm{FBG}_{1}$ and $\mathrm{FBG}_{2}$ that passed through the power combiner of the luminous flux (4) is shown in Fig. 7 a, and the spectral response that passed through the linear inclined filter is shown in Fig. 7 b. Continuous two-frequency laser radiation is received by a photodetector (6) Photodetector. The situational form of the electrical signal spectrum is shown in Fig. 7 c.

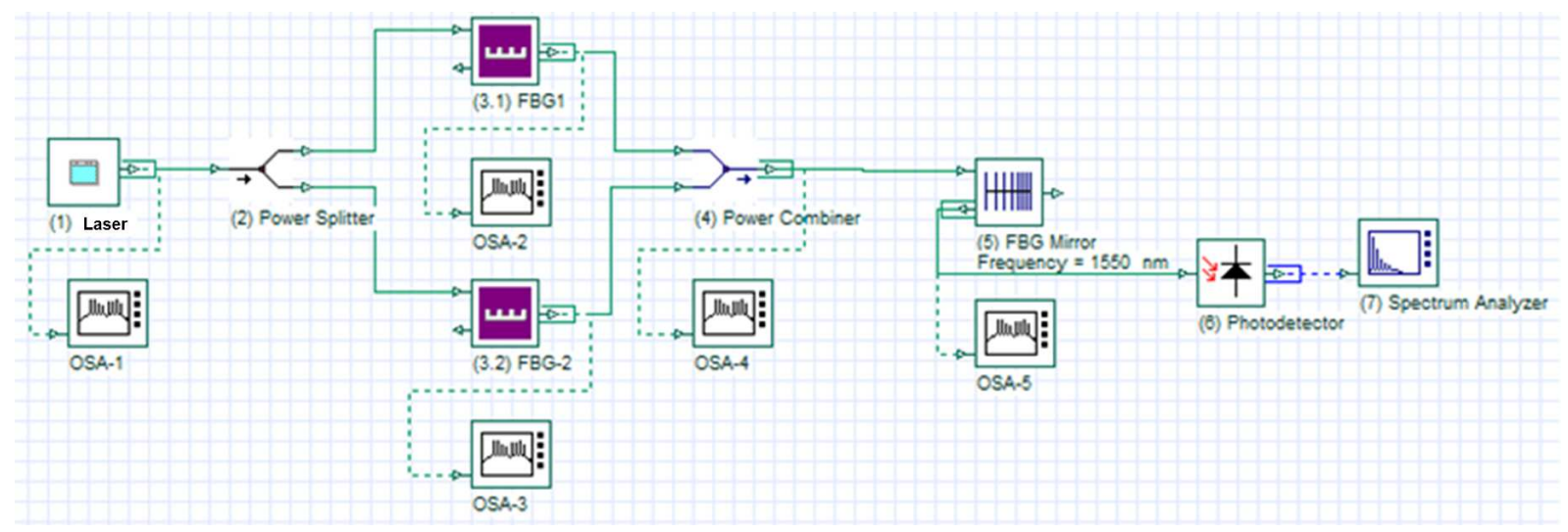

Fig. 6. Equivalent optoelectronic circuit for interrogating the acceleration sensor.

The spectrum clearly shows the oscillation frequency corresponding to the difference frequency between two frequency components of the optical signal.

In order to simulate an impact of the external dynamic force, the central wavelengths of $\mathrm{FBG}_{1}$ and $\mathrm{FBG}_{2}$ were synchronously shifted in the range [193.428216196, 193.4157368757] $\mathrm{THz}$ (from 1549.89 to $1549.99 \mathrm{~nm}$ ) for $\mathrm{FBG}_{1}$ and [193.4007638168, 193.413241412049] THz (from 1550.11 to $1550.01 \mathrm{~nm}$ ) for $\mathrm{FBG}_{2}$, where discrete step is $11.34 \mathrm{MHz}(10 \mathrm{pm}$ ), which provides 11 measurements. The resulting spectrum of oscillations of the electrical signal intensity is shown in Fig. 8. Each curve, highlighted in a separate color, corresponds to separate measurement.

The dependence of the normalized oscillation powers on the change in the central wavelengths of $\mathrm{FBG}_{1}$ and $\mathrm{FBG}_{2}$ is shown in Fig. 9. It is clear that the dependence of the normalized power of an electrical signal on the position of $\mathrm{FBG}_{1}$ and $\mathrm{FBG}_{2}$ is a monotonic function. Therefore, there is an one-to-one relationship between the Bragg frequency difference of two Bragg fiber gratings and the power the resulting signal $[2,5]$. 
불

OSA-4
Left Button and Drag to Select Zoom Region. Press Control Key and Left

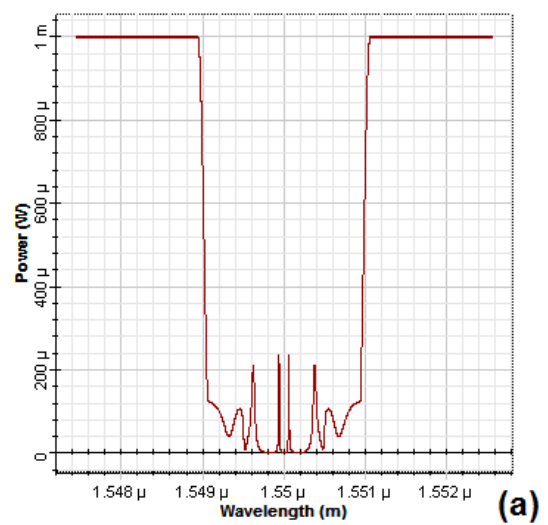

莦

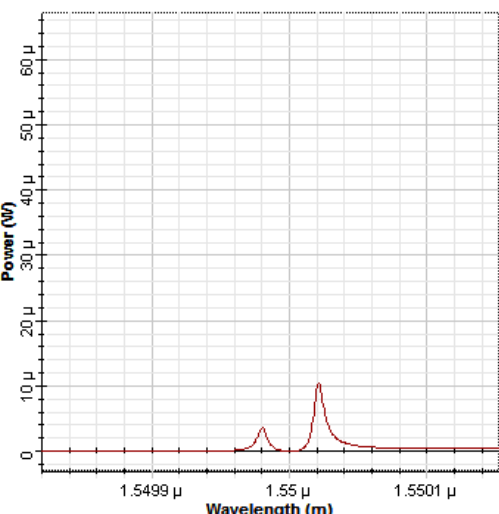

룰

(7) Spectrum Analyze

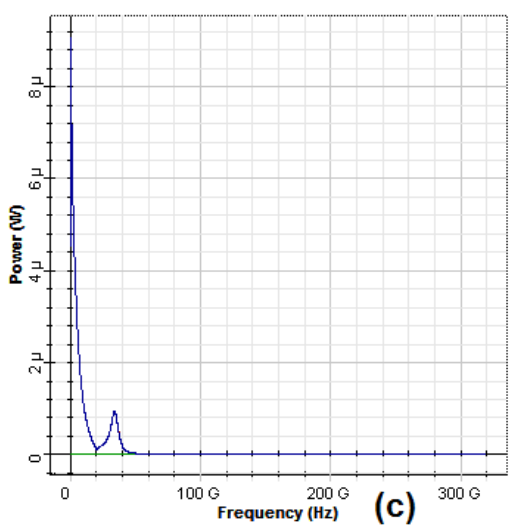

Fig. 7. Spectral characteristics: a) optical response from two FBGs; b) optical response from two FBGs after the inclined filter; c) spectral characteristic of the signal received at the photodetector.

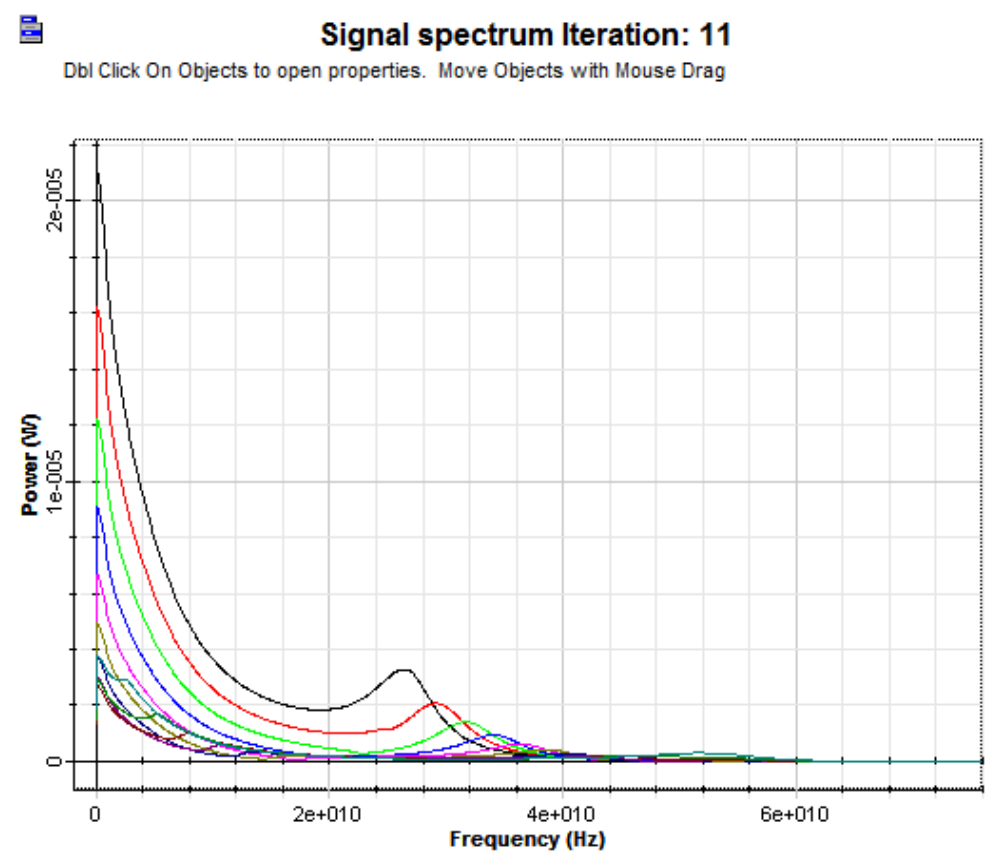

Fig. 8. Spectral characteristics of an electrical signal after passing through the frequency filter with an inclined amplitude-frequency characteristic: the colors in the figure indicate the spectral characteristics for each iteration.

Fig. 9 gives a dependence of the electrical signal power on the difference frequency. The dependence is non-linear and is determined by the curvature of the frequency inclined filter in the amplitude-frequency plane. Also, the dependence determines the general function of converting acceleration into an output signal. As a result, the dependence is subject to certification for each sensor sample. 


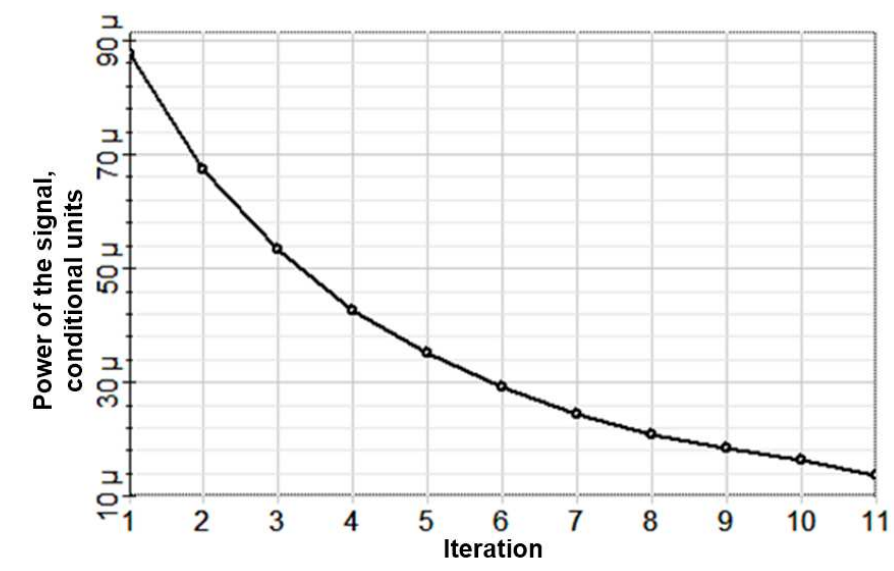

Fig. 9. Dependence of the normalized electrical signal power on the difference frequency.

\section{Conclusion}

As a result of the work, we present theoretical studies on the possibility to use fiber Bragg structures, in particular fiber Bragg gratings, as sensitive elements of a radiophoton measuring system designed to measure the acceleration of a physical object.

The entire measuring system consists of a laser source, a fiber-optic splitter and a power combiner, a constructive of sensitive element of the measuring system, a linear inclined filter, a photodetector and a unit to analyze the frequency of the received signal. Note that the an emission bandwidth of the laser is equivalent to the spectral width of the measuring range. The entire aggregate elemental base has minimal geometric dimensions. Therefore, the finished designed device can be very compact for subsequent use in inertial navigation systems of moving objects, as well as in accelerating or brake blocks of mechanisms, units and structures. The proposed element base does not contain expensive or rare components. In addition, all elements of the measuring system are easily replicable.

The immunity of the optical part of the measuring system to electromagnetic interference allows to use the proposed measuring system, with proper shielding of the photodetector and frequency analyzer, in those areas where the influence of such fields has a significant impact on the operation of traditional sensors.

Mathematical modeling of the proposed optoelectronic circuit of acceleration measurement confirmed that the radiophoton approach to construction allows to estimate the magnitude and direction of the effective acceleration, taking into account the stability of the method to temperature deviations and a potentially high signal/ noise ratio.

The theoretical study was carried out with the financial support of the Ministry of Education and Science of the Russian Federation within the framework of the state assignment of KNRTU-KAI № 8.6872.2017/8.9).

\section{References}

1. Dzhashitov V. E., Pankratov V. M. Detectors, Devices, and Systems of Aerospace and Marine Instrument Engineering under Thermal Influences. St. Petersburg, GNTa TsNII "Elektropribor", 2005. (in Russian). 
2. Garcia Y. R., Corres J. M., Goicoechea J. Vibration Detection Using Optical Fiber Sensors. Journal of Sensors, 2010, vol. 2010. DOI: 10.1155/2010/936487.

3. Gangopadhyay K. Prospects for Fibre Bragg Gratings and Fabry-Perot Interferometers in Fibre-Optic Vibration Sensing. Sensors and Actuators A, 2004, vol. 113, no. 1, pp. 20-38. DOI: $10.1155 / 2010 / 936487$.

4. Morozov O.G., Ilyin G.I., Morozov G.A. [The Systems of Radio Photonics with Amplitude-Phase Modulation Transformation Optical Bearing]. Kazan, Novoye Znaniye Publ., 2014. (in Russian).

5. Morozov O. G., Morozov G. A., Nureev I. I., Sakhabutdinov A. J., Artem'ev V. I. Radiophotonics Two-Frequency Methods for Interrogation of Similar Fiber Bragg Gratings, United to the Group. Physics of Wave Processes and Radio Systems, 2017, vol. 20, no. 2, pp. 21-34. (in Russian).

6. Agraval G. P., Radic S. Phase-Shifted Fiber Bragg Gratings and Their Application for Wavelength Demultiplexing. IEEE Photonic Technology Letters, 1994, vol. 6, no. 8, pp. 995-997. DOI: 10.1109/68.313074.

7. Guodan S., Rong W., Tao P. et. al. Analysis and Application of Phase Shift for Identical Multiple Wavelength Sampled Fiber Bragg Grating. Optics and Spectroscopy, 2012, vol. 42, no. 4, pp. 751-759.

8. Kersey A. D., Berkoff T. A., Morey W. W. Multiplexed Fiber Bragg Grating StrainSensor System with a Fiber Fabry-Perot Wavelength Filter. Optics Letters, 1993, vol. 18, no. 16, pp. 1370-1372. DOI: 10.1364/OL.18.001370.

Airat Zh. Sakhabutdinov, PhD (Math), Department of Radio Photonics and Microwave Technologies, Kazan National Research Technical University named after A. N. Tupolev (Kazan, Russian Federation), azhsakhabutdinov@kai.ru.

Vladimir V. Chistyakov, Department of Applied Mathematics and Rocket Dynamics, Director of the Research and Education Center "Rocket Engineering", Branch of South Ural State University (Miass, Russian Federation), niokr.chistyakov@gmail.com.

Oleg G. Morozov, DSc (Techn), Professor, Head of the Department of Radio Photonics and Microwave Technologies, Kazan National Research Technical University named after A. N. Tupolev (Kazan, Russian Federation), microoil@mail.ru.

Ilnur I. Nureev, DSc (Techn), Department of Radio Photonics and Microwave Technologies, Kazan National Research Technical University named after A. N. Tupolev (Kazan, Russian Federation), n2i2@mail.ru.

Artem A. Kuznetsov, PhD (Techn), Department of Radio Photonics and Microwave Technologies, Kazan National Research Technical University named after A. N. Tupolev (Kazan, Russian Federation), AAKuznetsov@kai.ru. 
Lenar M. Faskhutdinov, PhD (Techn), Department of Radio Photonics and Microwave Technologies, Kazan National Research Technical University named after A. N. Tupolev (Kazan, Russian Federation), lmfaskhutdinov@kai.ru.

Maxim V. Nosikov, Postgraduate Student, Department of Automatics, Head of Laboratory "Air Traffic Dynamics Modeling", Branch of South Ural State University (Miass, Russian Federation), maximnosikov@gmail.com.

Received November 22, 2018.

УДК 681.586.57

DOI: $10.14529 /$ jcem180402

\title{
ОПТОВОЛОКОННЫЙ ДАТЧИК УСКОРЕНИЯ НА СДВОЕННЫХ ВОЛОКОННЫХ БРЭГГОВСКИХ СТРУКТУРАХ
}

\author{
А. Ж. Сахабутдинов, В. В. Чистяков, О. Г. Морозов, И. И. Нуреев, \\ А. А. Кузнецов, Л. М. Фасхутдинов, М. В. Носиков
}

\begin{abstract}
В работе предлагается оценка возможности применения узкополосных волоконных брэгговских структур в качестве основы измерительной системы для датчика ускорения (акселерометра). Оценка применимости ведется на основе математического и компьютерного моделирования и аналитических оценок работоспособности модели. Задачу предлагается решать путем перевода оптического сигнала из оптического (ТГц) в радиочастотный диапазон измерений (ГГц) за счет теории и техники радиофотонных методов, что позволяет значительно повысить показатель отношения сигнал/шум. В основе измерительной системы предложено использовать две узкополосные волоконные брэгговские решетки с центральными частотами, лежащими в оптическом диапазоне, и разностью центральных частот в радиочастотном диапазоне спектра. Полученный в оптико-электронной схеме оптический сигнал, подается на фотоприемник, и по анализу результирующего электрического сигнала делается вывод о величине и направлении силы, действующей вдоль оси чувствительности датчика. Величина действующей силы инерции напрямую связана с действующим на измерительную систему ускорением. В работе предлагается подход к определению величины действующей силы, который не требует измерения промежуточной радиочастоты и предполагает построение зависимости действующей силы от величины коэффициента модуляции двухчастотных биений. Конструктивное исполнение датчика предлагается реализовать таким образом, чтобы минимизировать влияние девиаций температуры на измерительную систему в целом.

Ключевые слова: акселерометр; опто-волоконный датчик ускорения; двухчастотное лазерное излучение; волоконная брэгговская решетка с дискретным фазо-

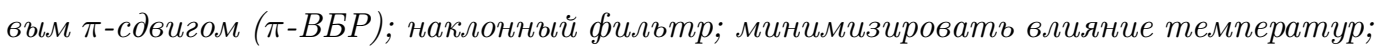
отклонения.
\end{abstract}

\section{Литература}

1. Джашитов, В. Э. Датчики, приборы и системы авиакосмического и морского приборостроения в условиях тепловых воздействий / В. Э. Джашитов, В. М. Панкратов, под ред. акад. РАН В. Г. Пешехонова. - СПб.: ГНЦ РФ - ЦНИИ «Электроприбор», 2005. 
2. Garcia, Y. R. Vibration Detection Using Optical Fiber Sensors / Y. R. Garcia, J. M. Corres, J. Goicoechea // Journal of Sensors. - 2010. - V. 2010.

3. Gangopadhyay, K. Prospects for Fibre Bragg Gratings and Fabry-Perot Interferometers in Fibre-Optic Vibration Sensing / K. Gangopadhyay // Sensors and Actuators A. - 2004. - V. 113, № 1. - P. 20-38.

4. Морозов, О. Г. Системы радиофотоники с амплитудно-фазовым модуляционным преобразованием оптической несущей / О. Г. Морозов, Г. И. Ильин, Г. А. Морозов; под ред. О. Г. Морозова. - Казань: Новое знание, 2014.

5. Морозов, О. Г. Радиофотонные двухчастотные способы интеррогации однотипных волоконных брэгговских решеток, объединенных в группу / О. Г. Морозов, Г. А. Морозов, И. И. Нуреев, А. Ж. Сахабутдинов, В. И. Артемьев // Физика волновых процессов и радиотехнические системы. - 2017. - Т. 20, № 2. - С. 21-34.

6. Agraval, G. P. Phase-Shifted Fiber Bragg Gratings and Their Application for Wavelength Demultiplexing / G. P. Agraval, S. Radic // IEEE Photonic Technology Letters. - 1994. - V. 6, № 8. - P. 995-997.

7. Guodan, S. Analysis and Application of Phase Shift for Identical Multiple Wavelength Sampled Fiber Bragg Grating / S. Guodan, W. Rong, P. Tao et. al. // Optica Applicata. - 2012. - V. 42, № 4. - P. 751-759.

8. Kersey, A. D. Multiplexed Fiber Bragg Grating Strain-Sensor System with a Fiber Fabry-Perot Wavelength Filter / A. D. Kersey, T. A. Berkoff, W. W. Morey // Optics Letters. - 1993. - V. 18, № 16. - P. 1370-1372.

Сахабутдинов Айрат Жавдатович, кандидат физико-математических наук, дочент кафедры радиоботоники и микроволновых технологий, Казанский национальный исследовательский технический университет им. А. Н. Туполева (г. Казань, Российская Федерачия), azhsakhabutdinov@kai.ru.

Чистяков Владимир Вильевич, преподаватель кафедры прикладной математики и ракетодинамики, директор научно-образовательного иентра «Ракетостроение», филиал Южно-Уральского государственного университета (г. Миасс, Российскал Федерация),niokr.chistyakov@gmail.com.

Морозов Олег Геннадъевич, доктор технических наук, профессор, заведующий кафедрой радиофотоники и микроволновых технологий, Казанский начиональный исследовательский технический университет им. А. Н. Туполева (г. Казань, Российская Федерачия), microoil@mail.ru.

Нуреев Ильнур Илъдарович, доктор технических наук, профессор кафедры радиофотоники и микроволновых технологий, Казанский национальный исследовательский технический университет им. А. Н. Туполева (г. Казань, Российская Федераuия),n2i2@mail.ru. 
Кузнецов Артем Анатольевич, кандидат технических наук, доцент кафедрь радиоботоники и микроволновых технологий, Казанский начиональный исследовательский технический университет им. А. Н. Туполева (г. Казань, Российская Федерачия), AAKuznetsov@kai.ru.

Фасхутдинов Ленар Маликович, кандидат технических наук, стариий преподаватель кафедры радиофотоники и микроволновых технологий, Казанский начиональный исследовательский технический университет им. А. Н. Туполева (г. Казанъ, Российская Федерачия), lmfaskhutdinov@kai.ru.

Носиков Максим Владимирович, аспирант, старший преподаватель кафедры автоматики, заведующий лабораторией «Моделирование динамики движения ЛА», филиал Южно-Уральского государственного университета (г. Миасс, Российская Федерация), maximnosikov@gmail.com.

Поступила в редакиию 22 ноября 2018 г. 